\title{
COMPLEX APPROACH TO ASSESSMENT OF COMPETITIVENESS OF POWER-GENERATING COMPANIES OF DEVELOPING ECONOMIES
}

\author{
A. DOMNIKOV, G. CHEBOTAREVA \& M. KHODOROVSKY \\ Academic Department of banking and investment management, Ural Federal University \\ named after the first President of Russia B.N. Yeltsin, Russia.
}

\begin{abstract}
The present-day trends in the economic development are characterized by both the processes of restructuring initiating investment activity and the mounting competitive pressure. These special characteristics clearly manifest themselves in the developing economies featuring low level of development of infrastructure - in the power sector in particular, and this gives rise to the development of specific forms of competition in the power-generating sphere. Finding solutions to the problems of development of energy infrastructure will be instrumental in strengthening the competitive position of the developing countries on the world market and reducing the threat of takeover. This paper presents a complex approach to assessment of competitiveness of power-generating companies in developing countries. Such an approach offers an opportunity to assess the attractiveness of current levels of investment of a company and its long-term sustainability through application of modern analytical tools. The practical aspects of the authors' methodological approach to the assessment of competitiveness are discussed using a Russian power-generating company as an example. The proposed ideas based on revealing the most risk-bearing hazards, those of latent nature including, may serve as a methodological basis for the development of risk management programmes in the power-generating sphere, to the benefit of realization of investment projects as well.

Keywords: bayes method, competitiveness, developing country, investment decision, power-generating company, risk, risk rating, 'TGK-9' JSC'.
\end{abstract}

\section{INTRODUCTION}

The process of competitive growth in power-generating companies presents a complex system of interrelations between power producers, consumers, investors and other parties in the matters of formation, maintaining and development of competitive advantages of powergenerating companies [1].

Analysis of modern approaches has revealed a series of principal drawbacks, among them being lack of necessary formalization accounting for sectoral specificity in the power-generating sphere proper, as well as prioritized qualitative assessment or analysis of financial and economic performance indicators only. [2].

Thus, an objective assessment of competitiveness of a power-generating company necessitates the development of a respective complex approach that facilitates making a decision on an investment project. Another important component of the process of assessment is identification and information-and-analytical support of risks as factors of competitiveness exerting direct impact on the development of power-generating companies, qualitative and quantitative assessment of their state and general risks rating.

The result of the study is the development of an original complex approach ensuring assessment of competitiveness of power-generating companies in developing countries. The obtained results are of practical value and are used in the development of new methodological tools of assessment of investment attractiveness of power-generating companies. 


\section{ELEMENTS OF COMPETITIVENESS OF POWER-GENERATING COMPANIES}

Within the scope of this article, the principal object of study is the competitiveness of a power-generating company, which is disclosed by studying the investment potential of a company. From this point of view, competitiveness is termed as the ability of a power-generating company to meet investor requirements related to fulfilment of terms of a deal, including full and timely payback and yield on investments in realization of an investment project. From the perspective of a long-term horizon, competitiveness also includes social demands of company owners concerning the assurance of reliable functioning of their company and adherence to high levels of quality of provided services.

Among the elements making the essence of competitiveness in the investment aspect, the following should be named:

1. Risk as a prospect of losses in case of partial or complete default of an investment project.

2. Investor attractiveness of a power-generating company [3].

3. Long-term sustainability of a power-generating company [4] etc.

\section{BASICS OF COMPLEX APPROACH TO ASSESSMENT OF COMPETITIVENESS OF POWER-GENERATING COMPANIES}

The complex approach to the assessment of competitiveness of power-generating companies in developing countries presents a complex and multi-level system comprising four main blocks of stages. The complex approach algorithm is shown in Fig. 1 [5].

Development of a complex approach is based on assessment of competitiveness of a power-generating company built upon multi-criteria ranking of sectoral risks, overall risk estimation, calculation of investment decision threshold value and assessment of the efficiency of risk mitigation measures.

Fulfilment of the above blocks is possible upon profound analysis of the financial and economic performance of a power-generating company combined with analysis of development tendencies of a region, including those specific for the company's business, which directly influence its production and economic performance indicators.

The preliminary stage envisages estimation of the real demand of a region for commissioning of additional power-generating capacities, estimation of expediency of setting up of a new power-generating facility or expansion of the existing one.

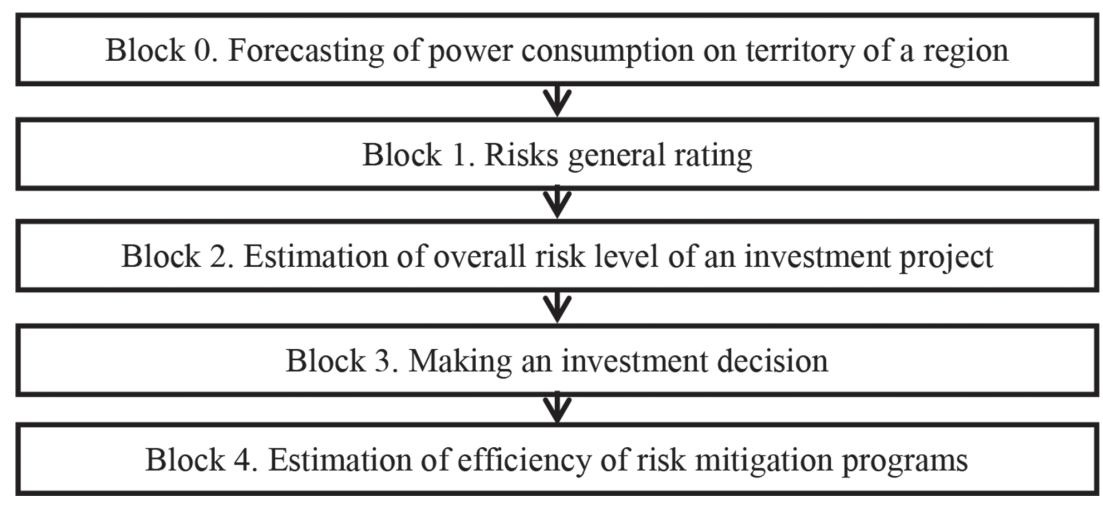

Figure 1: Algorithm of assessment of competitiveness of power-generating companies. 


\subsection{Power-generating company risks rating}

All-embracing rating of identified risks is attained at the expense of a complex system of calculations:

1. Statistical data standardization by risks.

2. Valuation of grade equivalent of standardized data.

3. Calculation of individual limits of risk states variation [6].

4. Calculation of risks realization probability.

5. Calculation of risks relative value within a group and so on.

General risks rating allows identification of the most hazard-bearing risks that may threaten retaining or improving the current competitive positions of a power-generating company. This is made possible by calculating the individual limits of risk states measurement and individual attribution of each risk to a certain state group.

Calculation of individual limits of risk states variation is carried out using the Bayesian treatment-based eqn (1) [6]:

$$
\begin{aligned}
\ln \left(c_{i} q_{i}\right)- & 0.5^{*}\left(\left(X-M_{i}\right)^{T} * S_{i}^{-1} *\left(X-M_{i}\right)-\ln \left|S_{i}\right|\right)- \\
& \left(\ln \left(c_{i+1} q_{i+1}\right)-0.5^{*}\left(\left(X-M_{i+1}\right)^{T} * S_{i+1}^{-1} *\left(X-M_{i+1}\right)-\ln \left|S_{i+1}\right|\right)\right)
\end{aligned}
$$

The first block of stages serves as a basis for hlgraphic risks analysis and overall risk estimation of an investment project.

\subsection{Overall risk of a power-generating company investment project}

This block of stages envisages the overall risk graphic interpretation and estimation of total indicator on its basis.

The overall risk graphic interpretation relies on the use of rating data, while in graphic analysis use is made of the maximum and minimum risk realization probability values as vectors limiting the value of the overall risk of an investment project.

The overall risk value estimation is carried out on the basis of the analysis of graphic interpretation and is defined as a mean of maximum and minimum overall risk values as per eqn (2):

$$
R=\frac{R^{\max }+R^{\min }}{2}
$$

where $\mathrm{R}$ - investment project overall risk; $\mathrm{R}^{\max }=\frac{1}{2} * \sum_{\mathrm{j}=1}^{\mathrm{n}}\left(\mathrm{p}_{\mathrm{j}}^{\max } * \mathrm{p}_{\mathrm{j}+1}^{\max } * \sin \gamma_{\mathrm{j}+1}\right)$ - overall risk maximum value; $\mathrm{R}^{\min }=\frac{1}{2} * \sum_{\mathrm{j}=1}^{\mathrm{n}}\left(\mathrm{p}_{\mathrm{j}}^{\min } * \mathrm{p}_{\mathrm{j}+1}^{\min } * \sin \gamma_{\mathrm{j}+1}\right)$ - overall risk minimum value; $\mathrm{p}_{\mathrm{j}}^{\max }$ maximum $\mathrm{j}$-th risk probability; $\mathrm{p}_{\mathrm{j}+1}^{\max }-\operatorname{maximum}(\mathrm{j}+1)$-th risk probability; $\gamma_{j+1}-(\mathrm{j}+1)$-th risk level of influence on competitiveness; $p_{j}^{\min }$ minimum $j$-th risk probability; $p_{j+1}^{\min }-$ minimum $(\mathrm{j}+1)$-th risk probability. 


\subsection{Assessment of investment decision made}

The investment decision that is taken characterizes the current level of competitiveness of a power-generating company as well as the available the margin of financial safety for meeting investors' credit requirements.

This block of stages bears upon the calculation of investment decision making thresholds using eqn (3) on the basis of estimation of overall risk actual value and the basic principles of economic capital:

$$
R_{\text {threshold }}=R *\left(1-\frac{\Delta C R}{C R_{\text {ФаKT }}}\right),
$$

where $\mathrm{R}_{\text {threshold }}$ - investment decision making threshold; $\mathrm{R}$ - investment project overall risk; $\Delta \mathrm{CR}=\mathrm{CR}_{r e q}-\mathrm{CR}_{a c t} ; \mathrm{CR}_{\text {req }}-$ power-generating company requirements to economic capital; $\mathrm{CR}_{a c t}$ - power-generating company economic capital actual value equal to amount of its net assets.

An investment decision is made by way of correlation of actual overall risk value and scale threshold calculated by eqn (4):

$$
\Delta R_{\text {final }}=R-R_{\text {threshold }},
$$

where $\Delta \mathrm{R}_{\text {final }}$ - difference between actual overall risk value and scale threshold value used in making an investment decision.

At difference value $\Delta \mathrm{R}_{\text {final }}>0$, the power-generating company is considered non-competitive and, therefore, a negative investment decision is taken. Here, the value $\Delta \mathrm{R}_{\text {final }}$ indicates the "excessive" amount of risk that needs to be minimized.

Contrary to this situation, at $\Delta \mathrm{R}_{\text {final }} \leq 0$, the power-generating company is considered competitive, and a positive investment decision is taken. The formed difference $\Delta R_{\text {final }}$ shows the amount of "financial reserve" for risks the company has.

\section{PRACTICAL ASSESSMENT OF COMPETITIVENESS OF A POWER- GENERATING COMPANY IN THE PROCESS OF REALIZATION OF AN INVESTMENT PROJECT}

Application of the complex approach described in Section 3 is based on the assessment of competitiveness of the Russian public power-generating company "T Plus" (before 2015, "TGK-9" JSC) made by studying identified risks: exogenous (characteristic of the region and the sector) and endogenous (inherent to the company).

Risks descriptions and results of their assessment in compliance with the approach are given below.

\subsection{Brief description of risks of public company "T Plus”,}

As an example of the application of a complex approach, typical sectoral risks that were most important in the operations of the power-generating company were studied. Risks are generally divided into exogenous and endogenous. More detailed risks classification testifies to their being a reflection of both the investment attractiveness of the region of location, its institutional and energy consumption and other spheres and the general economic and financial standing of the power-generating company. 
The classification and characteristics of risks under study and their defining indicators are given in Table 1.

Table 1: Classification of risks defining competitiveness of public company "T Plus".

\begin{tabular}{|c|c|c|c|c|}
\hline $\begin{array}{l}\text { Risk } \\
\text { group }\end{array}$ & $\begin{array}{l}\text { Risks } \\
\text { sphere }\end{array}$ & Risk description & Assessment tools & No. \\
\hline \multirow[t]{13}{*}{$\begin{array}{l}\text { Exog- } \\
\text { enous }\end{array}$} & \multirow{3}{*}{$\begin{array}{l}\text { Econo- } \\
\text { my of a } \\
\text { region }\end{array}$} & $\begin{array}{l}\text { Drop in gross regional product } \\
\text { (GRP) }\end{array}$ & GRP dynamics & 1 \\
\hline & & $\begin{array}{l}\text { Recession in the production of } \\
\text { specialization branches of a region }\end{array}$ & $\begin{array}{l}\text { Industrial production index } \\
\text { dynamics }\end{array}$ & 2 \\
\hline & & $\begin{array}{l}\text { Drop in investments in fixed } \\
\text { capital in a region }\end{array}$ & $\begin{array}{l}\text { Dynamics of investments in } \\
\text { a region }\end{array}$ & 3 \\
\hline & \multirow{2}{*}{$\begin{array}{l}\text { Fuel and } \\
\text { energy } \\
\text { balance }\end{array}$} & $\begin{array}{l}\text { Reduction of technological } \\
\text { diversification }\end{array}$ & $\begin{array}{l}\text { Variation of technological } \\
\text { diversification factor }\end{array}$ & 4 \\
\hline & & $\begin{array}{l}\text { Decrease in secondary power } \\
\text { resources endowment }\end{array}$ & $\begin{array}{l}\text { Dynamics of share of energy } \\
\text { generated by own sources in } \\
\text { a region }\end{array}$ & 5 \\
\hline & \multirow{4}{*}{$\begin{array}{l}\text { Institu- } \\
\text { tional } \\
\text { sphere }\end{array}$} & Rates policy failure & Dynamics of energy rates & 6,7 \\
\hline & & & $\begin{array}{l}\text { Dynamics of thermal energy } \\
\text { rates }\end{array}$ & 8,9 \\
\hline & & Exchange policy failure & $\begin{array}{l}\text { Dynamics of mean weighted } \\
\text { exchange rate (USD) }\end{array}$ & 10 \\
\hline & & Credit policy failure & $\begin{array}{l}\text { Dynamics of mean weighted } \\
\text { interest rate for credits }\end{array}$ & 11 \\
\hline & \multirow{4}{*}{$\begin{array}{l}\text { Power } \\
\text { con- } \\
\text { sump- } \\
\text { tion }\end{array}$} & $\begin{array}{l}\text { Low economic efficiency of elec- } \\
\text { tric energy resources: }\end{array}$ & & \\
\hline & & In industrial sector & $\begin{array}{l}\text { Dynamics of GRP energy } \\
\text { intensity }\end{array}$ & 12 \\
\hline & & In domestic household sector & $\begin{array}{l}\text { Dynamics of per capita } \\
\text { electric energy resources } \\
\text { consumption }\end{array}$ & 13 \\
\hline & & Energy inefficiency & $\begin{array}{l}\text { Dynamics of decentral- } \\
\text { ized system's share in total } \\
\text { energy consumption }\end{array}$ & 14 \\
\hline
\end{tabular}

(Continued) 
Table 1: (Continued)

\begin{tabular}{|c|c|c|c|c|}
\hline $\begin{array}{l}\text { Risk } \\
\text { group }\end{array}$ & $\begin{array}{l}\text { Risks } \\
\text { sphere }\end{array}$ & Risk description & Assessment tools & No. \\
\hline \multirow[t]{7}{*}{$\begin{array}{l}\text { Endog- } \\
\text { enous }\end{array}$} & \multirow{5}{*}{$\begin{array}{l}\text { Cor- } \\
\text { porate } \\
\text { finance }\end{array}$} & Increase in direct financial losses & $\begin{array}{l}\text { Dynamics of accounts } \\
\text { receivable }\end{array}$ & 15 \\
\hline & & $\begin{array}{l}\text { Decrease in operating surplus of } \\
\text { power-generating companies }\end{array}$ & Dynamics of EBITDA & 16 \\
\hline & & $\begin{array}{l}\text { Decrease in investments in } \\
\text { power-generating companies }\end{array}$ & $\begin{array}{l}\text { Dynamics of investments in } \\
\text { fixed capital }\end{array}$ & 17 \\
\hline & & Company value drop & Dynamics of charge of value & 18 \\
\hline & & $\begin{array}{l}\text { Impairment of standing in stock } \\
\text { market }\end{array}$ & Dynamics of $E P S$ & 19 \\
\hline & \multirow[t]{2}{*}{$\begin{array}{l}\text { Econo- } \\
\text { my }\end{array}$} & $\begin{array}{l}\text { Increase in reliance on imported } \\
\text { equipment }\end{array}$ & $\begin{array}{l}\text { Share of imported equip- } \\
\text { ment on the overall volume } \\
\text { of plant and equipment }\end{array}$ & 20 \\
\hline & & $\begin{array}{l}\text { Increase in rate of equipment } \\
\text { wear }\end{array}$ & $\begin{array}{l}\text { Dynamics of share of over- } \\
\text { aged equipment }\end{array}$ & 21 \\
\hline
\end{tabular}

4.2 General sectoral risks rating at public company "T Plus",

Ranking of sectoral risks of a power-generating company is based on the principle of multifactor rating. The main criteria under such an approach are: state group identity of each risk calculated by eqn (1) and risk relative value within the group. Maximum and minimum probabilities of each risk realization are regarded as additional rating criteria.

Within the framework of the present study, four possible risk states and effect levels are considered: minimum, admissible, high and critical.

The basis for the calculation of state variation limits for each sectoral risk, as well as its relative risk value is the statistical distribution of data of risk indicators for the period between 2003 and 2015. The calculations carried out in compliance with Block 1 allowed sectoral risks rating as shown in Table 2.

Thus, the most threatening factors for critical risk effect within the scope of the given investment project are the exogenous risks connected with increase in the share of decentralized systems in the overall amount of energy consumption, and the endogenous risks that determine increase of power-generating companies' dependence on imported equipment. The least threat level is indicated by risks characterizing pricing in the sector. At that, the minimum threat is shown for the exogenous risk reflecting the rates policy in the sphere of electric energy for industrial enterprises of the region. The main reason for such a minimum level of risk effect is the permanent growth of its key determining factor over the entire period under study. 
Table 2: General sectoral risks rating at public company "T Plus".

\begin{tabular}{|c|c|c|c|c|c|}
\hline Rating & $\begin{array}{l}\text { Desig- } \\
\text { nation }\end{array}$ & Risk description & $\begin{array}{l}\text { Risk } \\
\text { state } \\
\text { group }\end{array}$ & $\begin{array}{l}\text { Risk } \\
\text { rela- } \\
\text { tive } \\
\text { value }\end{array}$ & $\begin{array}{l}\text { Maximum } \\
\text { risk } \\
\text { probability }\end{array}$ \\
\hline 1 & $X_{14}$ & Sverdlovsk Oblast energy efficiency & \multirow{6}{*}{$\begin{array}{l}\text { Criti- } \\
\text { cal risk } \\
\text { effect } \\
\text { level }\end{array}$} & $\rightarrow 1.00$ & 0.9091 \\
\hline 1 & $X_{20}$ & $\begin{array}{l}\text { Growth of dependence on imported equip- } \\
\text { ment at Public Company 'T PLUS' }\end{array}$ & & $\rightarrow 1.00$ & 0.9091 \\
\hline 3 & $X_{15}$ & $\begin{array}{l}\text { Increase in direct financial losses at Public } \\
\text { Company 'T PLUS' }\end{array}$ & & $\rightarrow 1.00$ & 0.8182 \\
\hline 4 & $X_{21}$ & $\begin{array}{l}\text { Increase in rate of equipment wear at Public } \\
\text { Company 'T PLUS' }\end{array}$ & & $\rightarrow 1.00$ & 0.6364 \\
\hline 5 & $X_{10}$ & Inefficient exchange policy & & $\rightarrow 1.00$ & 0.5455 \\
\hline 6 & $X_{2}$ & $\begin{array}{l}\text { Retardation in the development of special- } \\
\text { ized branches of Sverdlovsk Oblast }\end{array}$ & & 0.5500 & - \\
\hline 7 & $X_{13}$ & $\begin{array}{l}\text { Inefficient use of energy resources in the } \\
\text { domestic household sector of Sverdlovsk } \\
\text { Oblast }\end{array}$ & $\begin{array}{l}\text { High } \\
\text { risk } \\
\text { effect } \\
\text { level }\end{array}$ & - & - \\
\hline 8 & $X_{19}$ & $\begin{array}{l}\text { Impaired standing of Public Company 'T } \\
\text { PLUS' on the stock market }\end{array}$ & \multirow{5}{*}{$\begin{array}{l}\text { Admis- } \\
\text { sible } \\
\text { risk } \\
\text { effect } \\
\text { level }\end{array}$} & 0.9659 & - \\
\hline 9 & $X_{16}$ & $\begin{array}{l}\text { Decrease in operating surplus of Public } \\
\text { Company 'T PLUS' }\end{array}$ & & 0.9097 & - \\
\hline 10 & $X_{4}$ & $\begin{array}{l}\text { Reduction of technological diversification in } \\
\text { Sverdlovsk Oblast }\end{array}$ & & 0.7961 & - \\
\hline 11 & $X_{5}$ & $\begin{array}{l}\text { Drop of secondary energy resources avail- } \\
\text { ability level in Sverdlovsk Oblast }\end{array}$ & & 0.5441 & - \\
\hline 12 & $X_{11}$ & Inefficient credit policy & & 0.4580 & - \\
\hline 13 & $X_{17}$ & $\begin{array}{l}\text { Decrease in investments in Public Company } \\
\text { 'T PLUS' }\end{array}$ & \multirow{4}{*}{$\begin{array}{l}\text { Mini- } \\
\text { mum } \\
\text { risk } \\
\text { effect } \\
\text { level }\end{array}$} & 0.1621 & - \\
\hline 14 & $X_{3}$ & $\begin{array}{l}\text { Decrease in investments in fixed capital in } \\
\text { Sverdlovsk Oblast }\end{array}$ & & 0.0713 & - \\
\hline 15 & $X_{12}$ & $\begin{array}{l}\text { Inefficient use of energy resources in Sverd- } \\
\text { lovsk Oblast industrial sector }\end{array}$ & & 0.0381 & - \\
\hline 16 & $X_{1}$ & $\begin{array}{l}\text { Decrease in gross regional product of } \\
\text { Sverdlovsk Oblast }\end{array}$ & & 0.0104 & - \\
\hline
\end{tabular}


Table 2: (Continued)

\begin{tabular}{|c|c|c|c|c|c|}
\hline Rating & $\begin{array}{l}\text { Desig- } \\
\text { nation }\end{array}$ & Risk description & $\begin{array}{l}\text { Risk } \\
\text { state } \\
\text { group }\end{array}$ & $\begin{array}{l}\text { Risk } \\
\text { rela- } \\
\text { tive } \\
\text { value }\end{array}$ & $\begin{array}{l}\text { Maximum } \\
\text { risk } \\
\text { probability }\end{array}$ \\
\hline 17 & $X_{18}$ & $\begin{array}{l}\text { Decrease in value of Public Company ' } T \\
\text { PLUS' }\end{array}$ & & 0.0052 & - \\
\hline 18 & $X_{6}$ & $\begin{array}{l}\text { Inefficient electric power rates policy for } \\
\text { domestic household sector in Sverdlovsk } \\
\text { Oblast }\end{array}$ & & 0.0046 & - \\
\hline 19 & $X_{7}$ & $\begin{array}{l}\text { Inefficient heat supply rates policy for } \\
\text { domestic household sector in Sverdlovsk } \\
\text { Oblast }\end{array}$ & & 0.0039 & - \\
\hline 20 & $X_{9}$ & $\begin{array}{l}\text { Inefficient thermal energy rates policy for } \\
\text { industrial sector in Sverdlovsk Oblast }\end{array}$ & & 0.0029 & - \\
\hline 21 & $X_{8}$ & $\begin{array}{l}\text { Inefficient electric power rates policy for } \\
\text { industrial sector in Sverdlovsk Oblast }\end{array}$ & & 0.0028 & - \\
\hline
\end{tabular}

\subsection{Assessment of competitiveness of public company 'T Plus'}

Assessment of the competitive status of the power-generating Public Company 'T Plus' is based on a study of the company's investment project overall risk scenarios, and the final matrix of investment decision making.

The main point of the Company 'T Plus' investment project under consideration is the construction of a new power generating facility: the 'Academicheskaya' Thermal Power Station.

At that, the ability of the Company to assume investment obligations for realizing an investment project will testify to a high level of its competitiveness. Otherwise, development of a respective mechanism will be necessary for improving "its competitive standing and intensifying investment activities.

\subsubsection{Competitiveness Scenarios of Public Company 'T Plus'}

The scenarios of competitiveness of the Public Company 'T Plus' considered in the framework of the present study are based on expert evaluation and vary depending on the trends of economic development, and thereby, on power demand on the side of the industrial sector of the region contemplated in one or the other scenario:

'Optimistic': a scenario proceeding from the assumption of active development of the economy and government support to realization of infrastructure projects, combined with sustainable growth of demand for electric power.

'Neutral': a scenario relying on the preservation of inertial trends in the development of the economy and slowdown of industrial production growth.

'Pessimistic': a scenario based on a hypothesis of slackening of a situation on the Russian energy market and drop of demand for energy resources. 
Based on the intuitive logic method, the principal indicators influencing competitiveness of the Public Company 'T Plus' were derived, which were in compliance with the scenarios presented in Table 3.

\subsubsection{Estimation of overall risk of investment project of public company 'T Plus'}

Estimation of overall risk of the investment project of the Public Company 'T Plus' for construction of a thermal power plant varies depending on the competitive scenarios prevalent in power-generating companies and the presumed value of risk input horizon $\mathrm{G}_{\mathrm{i}}$. The estimate results are shown in Table 4.

Comparison of the obtained results shows that the 'Pessimistic' scenario is characterized by the highest level of overall risk. Increase of the overall risk indicator relative to the 'Optimistic' scenario was 1.86 times, and that relative to the 'Pessimistic' scenario was 1.53 times. The 'Neutral' and 'Optimistic' scenarios are marked for significantly lower level of overall risk at preset risk input horizon: 1.0400 and 0.8547 , respectively.

\subsubsection{Making a final investment decision for public company 'T Plus'}

Making an investment decision on a project envisages comparison of values: the actual overall risk value $(\mathrm{R})$ and the respective threshold value $\left(\mathrm{R}_{\text {threshold }}\right)$.

Within the framework of this study, the additional tool used for the estimation of threshold values on the scale of investment decision making was the Merton-Vasicek model [7-9] employed for the evaluation of the economic capital of a power-generating company [10]. Simultaneously, several types of economic capital are considered: with and without account for penalties for investment phase duration and for the expected investors' rate of payback.

The results of the assessment of making the final investment decision and its graphic interpretation, are shown in Table 5, respectively, where CR are requirements of the company's economic capital accounting for penalty for investment phase duration (over one year), and

Table 3: Indicators of competitiveness scenarios of public company 'T Plus'.

\begin{tabular}{lllllll}
\hline Scenario & $\begin{array}{c}\text { Risk input } \\
\text { horizon, } G_{i}, \\
\%\end{array}$ & $\begin{array}{c}\text { Project } \\
\text { duration, } T, \\
\text { years }\end{array}$ & $\begin{array}{c}\text { Annual } \\
\text { percentage } \\
\text { yield, } \%\end{array}$ & $L G D, \%$ & Rating & $\begin{array}{c}\text { Project cost, } \\
\text { billion rub. }\end{array}$ \\
\hline 'Optimistic' & $1 /-1$ & 2 & 20 & 5 & $A$ & 10 \\
'Neutral' & $13 /-13$ & 2.5 & 15 & 10 & $B B$ & \\
'Pessimistic' & $120 /-120$ & 3 & 10 & 15 & $C C C$ & \\
\hline
\end{tabular}

Table 4: Overall risk of investment project of the Public Company 'T Plus'.

\begin{tabular}{llll}
\hline \multicolumn{1}{c}{ Scenarios } & \multicolumn{1}{c}{ 'Optimistic' } & 'Neutral' & 'Pessimistic' \\
\hline Overall risk, $R$ & 0,8547 & 1.0400 & 1.5889 \\
Increase relative to 'Optimistic' scenario & - & 1.22 times & 1.86 times \\
Increase relative to 'Neutral' scenario & - & - & 1.53 times \\
\hline
\end{tabular}


Table 5: Distribution of threshold values on scale of investment decision making.

\begin{tabular}{|c|c|c|c|c|c|c|}
\hline \multirow{3}{*}{ No. } & \multirow{3}{*}{ Scenario } & \multirow{3}{*}{$\begin{array}{l}\text { Overall } \\
\text { risk, } R\end{array}$} & \multicolumn{4}{|c|}{ Scale thresholds by scenarios and types of economic capital } \\
\hline & & & \multicolumn{2}{|c|}{$\begin{array}{l}\text { Accounting for investor's } \\
\text { payback }\end{array}$} & \multicolumn{2}{|c|}{$\begin{array}{l}\text { Without accounting for } \\
\text { investor's payback }\end{array}$} \\
\hline & & & $C R$ & $\mathrm{CaR}$ & $C R$ & $\mathrm{CaR}$ \\
\hline 1 & 'Optimistic' & 0.8547 & 0.9762 & 1.4658 & 1.1857 & 1.5354 \\
\hline 2 & 'Neutral' & 1.0400 & 0.4129 & 1.6047 & 0.8675 & 1.7343 \\
\hline 3 & 'Pessimistic' & 1.5889 & 0.9211 & 2.6143 & 1.4418 & 2.7443 \\
\hline
\end{tabular}

Table 6: Distribution of strength margin of economic capital of the Public Company 'T Plus'.

\begin{tabular}{|c|c|c|c|c|c|}
\hline \multirow[b]{2}{*}{ No } & \multirow[b]{2}{*}{ Scenario } & \multicolumn{2}{|c|}{ With accounting for payback level } & \multicolumn{2}{|c|}{ W/o accounting for payback; level } \\
\hline & & $\begin{array}{c}\Delta C R, \text { Billion } \\
\text { Rub. }\end{array}$ & $\begin{array}{l}\Delta C a R, \text { Billion } \\
\text { Rub. }\end{array}$ & $\begin{array}{l}\Delta C R, \text { Billion } \\
\text { Rub. }\end{array}$ & $\begin{array}{l}\Delta C a R, \text { Billion } \\
\text { Rub. }\end{array}$ \\
\hline 1 & 'Optimistic' & 0.1644 & 0.8265 & 0.4477 & 0.9207 \\
\hline 2 & 'Neutral' & -0.6971 & 0.6277 & -0.1917 & 0.7718 \\
\hline 3 & 'Pessimistic' & -0.4859 & 0.7460 & -0.1070 & 0.8406 \\
\hline
\end{tabular}

$\mathrm{CaR}$ are requirements for the company's economic capital without accounting for penalty for investment phase duration [10].

It may be seen from the obtained results that in putting maximum requirements to economic capital, the company will remain competitive only in the 'Optimistic' scenario case, with the strength margin for risks at $\Delta \mathrm{R}_{\text {optim }}=0.1215$. In other cases, at 'Neutral' and 'Pessimistic' scenarios, the company becomes non-competitive and is challenged by the need for recovery of losses for risks at $\Delta \mathrm{R}_{\text {neutr }}=0.6271$ and $\Delta \mathrm{R}_{\text {pessim }}=0.6678$, respectively. Further analysis has shown that, with the 'Optimistic' scenario, the 'T Plus' is an absolutely competitive company with respect to requirements to its economic capital, and its strength margin expands with its requirements relaxation.

The distribution of strength margin of company's capital designed for risks coverage is shown in Table 6, where the negative value points to the capital in need for additional supplementing.

Thus, with the 'Optimistic' scenario, the Public Company 'T Plus' is absolutely competitive. This implies an opportunity for realization of the investment project under consideration in full, with no risks of default or prospects for uncovered losses to be suffered by investors.

In case of the 'Neutral' or 'Pessimistic' scenarios, the power-generating company is definitely non-competitive and there is high probability that, in conditions of maximum requirements to its capital, it will be unable to meet the 'risk challenge'. This stimulates the development of additional mechanisms aimed at decreasing the burden on the power-generating company's capital at the expense of sectoral risks management and improving competitiveness with intensified investment activities. 


\section{CONCLUSIONS}

In many respects, the competitiveness of a power-generating company depends on its ability to sustain functioning and generation of cash flows. In this context, the key factor is the problem of risk management, and its solution is a pre-requisite to securing the long-term sustainability of a company. The said problem acquires particular importance in conditions of realization of investment projects, with prospects for either raising efficiency and expansion of a business, or a company's default [4]. As calculations have shown, the risk minimum value is the case with an investment project in the 'Optimistic' scenario. In the 'Neutral' and 'Pessimistic' scenarios, on the contrary, the overall risk increases by $22 \%$ and $86 \%$, respectively, predominantly at the expense of reducing the remote possibility of realization of development risks.

Proceeding from scenario-related estimates, an analysis of competitiveness of a powergenerating company was carried out. The results of the analysis have brought us to a conclusion that the power-generating company attains absolute investor attractiveness only in case of an 'Optimistic' scenario. In the 'Neutral' and 'Pessimistic' scenarios, the power-generating company lacks investor attractiveness. From this follows the necessity of meeting the additional growing demand for capital within the scope of the given scenarios with a view to enter the zone of attractiveness and attaining a positive investment decision.

The described complex approach, though based on the broadly used models in the risk management theory, presents a totally new method applied to power-generating companies in developing countries and for ranking of risks and estimation of their overall value, offering an opportunity to counter-balance subjective expert assessments.

Notwithstanding the foregoing, the given approach for the assessment of competitiveness of power-generating companies has a number of disadvantages that are mainly due to the complexity and scale of the calculations made. Another problem lies in the development of a correct approach for the actual evaluation of economic capital of a power-generating company properly accounting for modern requirements and special characteristics corporate financing. Finding solutions to the above problems will allow ensuring sustainable development of power-generating companies under conditions of high sectoral risks.

\section{ACKNOWLEDGEMENT}

The work was supported by Act 211 of Government of the Russian Federation, contract No. 02.A03.21.0006.

\section{REFERENCES}

[1] Domnikov, A., Chebotareva, G. \& Khodorovsky, M., Evaluation of investor attractiveness of power-generating companies: special reference to the development risks of the electric power industry. WIT Transactions on Ecology and the Environment, 190, pp. 199-210, 2014. http://dx.doi.org/10.2495/EQ140211

[2] Domnikov, A., Chebotareva, G. \& Khodorovsky, M., Evaluation of investor attractiveness of power-generating companies, given the specificity of the development risks of electric power industry. Vestnik UrFU, 3, pp. 15-25, 2013.

[3] Domnikov, A., Khomenko, P. \& Chebotareva, G., A risk-oriented approach to capital management at a power generation company in Russia. WIT Transactions on Ecology and the Environment, 186, pp. 13-24, 2014.

http://dx.doi.org/10.2495/ESUS140021 
[4] Domnikov, A., Chebotareva, G., Khomenko, P. \& Khodorovskiy, M., Risk-oriented approach to long-term sustainability management for oil and gas companies in the course of implementation of investment projects. WIT Transactions on Ecology and the Environment, 192, pp. 275-284, 2015.

http://dx.doi.org/10.2495/ECO150251

[5] Khodorovsky, M., Domnikov, A. \& Chebotareva, G., Classification of investor attractiveness risks in high-precision industries: a qualitative aspects (by example of electricity). Vestnik SUSU, 2, pp. 99-106, 2014.

[6] Domnikov, A., Chebotareva, G. \& Khodorovskiy, M., Development of risk management for power generating companies in developing countries. WIT Transactions on Ecology and the Environment, 193, pp. 859-870, 2015.

http://dx.doi.org/10.2495/SDP150721

[7] Merton, R.C., On the pricing of corporate debt: the risk structure of interest rates. Journal of Finance, 29, pp. 449-470, 1974. http://dx.doi.org/10.1111/j.1540-6261.1974.tb03058.x

[8] Vasicek, O., Loan portfolio value. Credit Portfolio Models, 15, pp. 160-162, 2002.

[9] Gorby, M.B., A risk-factor model foundation for rating-based bank capital rules. Journal of Financial Intermediation, 25, pp. 199-232, 2003. https://doi.org/10.1016/s1042-9573(03)00040-8

[10] Basel Committee on Banking Supervision 'International regulatory framework for banks'. Available at: www.bis.org 